Kalinowski M. (2014). Stock Exchanges Sustainability Support Assessment. Copernican Journal of Finance \& Accounting, 3(2), 37-48. http://dx.doi.org/10.12775/CJFA.2014.016

\author{
Marcin Kalinowski \\ Gdansk School of Banking
}

\title{
STOCK EXCHANGES SUSTAINABILITY SUPPORT ASSESSMENT
}

Keywords: sustainability, stock exchange, Sustainability Support Index.

\section{J E L Classification: Q56, G15.}

Abstract: Financial markets can play a role in sustaiability development. They can support sustainability by making ESG disclosure, launching sustainability related indices or offering sustainability guidance for listing companies. All of these activities helps in developing sustainability. This article is an attempt to analyze sustainability support level in stock exchanges in the world. It is based on a survey conducted in 27 stock exchanges. The aim of this article is to assess the level of stock exchanges sustainability support and examine the relationship between the stock market size and sustainability support level. To acheve the aim the assessment tool has been created. Sustainability Support Index is a synthetic stock markets sustainability support measure. It helps to compare stock exchange sustainability support levels. In the article statistical tools are used to compare the phenomena, mainly regression analysis and Pearson's correlation.

The conclusion presented in the article states that there is a differential stock market sustainability support level in the world. There is no clear correlation between sustainability support variables and stock market size variables.

Translated by Marcin Kalinowski

\section{OCENA WSPARCIA ZRÓWNOWAŻONEGO ROZWOJU NA GIEEDACH AKCJI}

Słowa kluczowe: zrównoważony rozwój, giełda papierów wartościowych, indeks wsparcia zrównoważonego rozwoju.

Date of submission: June 4, 2014; date of acceptance: August 13, 2014.

* Contact information: mkalinowski@wsb.gda.pl, Gdansk School of Banking, Dolna Brama 8, 80-821 Gdańsk, Poland, phone: 609880094. 
Klasyfikacja J E L: Q56, G15.

\begin{abstract}
Abstrakt: Rynki finansowe mogą odgrywać pewną rolę w zrównoważonym rozwoju. Rynki te mogą wspierać zrównoważony rozwój poprzez ujawnienie własnej polityki dotyczącej środowiska, spraw społecznych i ładu korporacyjnego (ESG). Zrównoważony rozwój może być również wspierany przez rynek akcji poprzez tworzenie indeksów zrównoważonego rozwoju oraz oferowanie wytycznych dotyczących zrównoważonego rozwoju dla notowanych firm. Wszystkie te aktywności wspierają zrównoważony rozwój. Artykuł ten stanowi próbę oceny poziomu wsparcia zrównoważonego rozwoju światowego rynku papierów wartościowych. Analiza ta opiera się na badaniach ankietowych przeprowadzonych na 27 rynkach akcji. Celem artykułu jest ocena poziomu wsparcia zrównoważonego rozwoju na rynkach akcji i zbadanie zależności pomiędzy wielkością rynku akcji a poziomem wsparcia zrównoważonego rozwoju. Dla realizacji celu w pracy stworzono narzędzie oceny zrównoważonego rozwoju (Sustainability Support Index - SSI). SSI jest syntetyczną miarą poziomu zrównoważonego rozwoju na rynku akcji. Narzędzie to pomaga w porównywaniu rynków akcji w analizowanym zakresie. W celu dokonania analizy porównawczej w artykule wykorzystano narzędzia statystyczne takie jak analiza regresji i wskaźnik korelacji Pearsona.

Podsumowując należy stwierdzić, że przeprowadzone badania wskazują, że poziom wsparcia zrównoważonego rozwoju na rynku akcji na świecie jest zróżnicowany. Ponadto nie można stwierdzić jednoznacznej i istotnej zależności pomiędzy zmiennymi dotyczącymi wsparcia zrównoważonego rozwoju i w zakresie wielkości rynku akcji.
\end{abstract}

\title{
INTRODUCTION
}

Sustainability is a trendy word. The problem is to find the understanding of that concept and implement it in various sectors of the economy. One of the elements of this structure is the financial sector. Guintessential questions can be developed on this basis: Can financial markets institutions develop and support sustainability? What is the sustainability support level in different financial markets? What are the relationship between sustainability support variables and stock markets size?

The basic question is to what extent business sustainability is contributing to sustainable development. There is a discussion about it in expert literature.

Banerjee $(2011,720)$ suggests that there are ideological barriers that are considered when business sustainability is approached from the economiccentered paradigm. These barriers include the benefits perspective for the organization (such as increasing brand value, reducing risk and cost factors, embracing new revenue growth potential) rather than covering a more balanced approach to value creation. Often, such benefits are called "win-win" approaches (Dyllick, Muff 2013). The dominant view is that business can profit from sustainability when solving the social and environmental problems of the world 
through new growth opportunities (Hart 2007), through opportunities for innovation (Nidumolo et al., 2009) or for profit (Prahalad, Hammond 2002; Prahalad 2004). The underlying assumption set in this perspective is that business will not pursue environmental and social initiatives if these do not provide economic advantages to the business.

Banerjee (2011) arrives at the same conclusion with regard to corporate social responsibility (CSR) and links it to the primary focus in the literature on the financial impact and on the company not on the outcomes for society. Margolis \& Walsh $(2003,289)$ conclude more broadly from their appraisal of 30 years of studies on corporate social performance: "Although the financial effects of corporate social performance have been extensively studied, little is known about any consequences of corporate social initiatives. Most notable, as calls for corporate involvement increase, there is a vital need to understand how corporate efforts to redress social misery actually affect their intended beneficiaries."

Analyzing this literature we can realize how difficult it is to point and realize sustainability assumptions especially in the financial sector. This article is focused on specific type of financial institutions - stock exchanges.

Stock Exchanges can play a major role in facilitating transparency of sustainability risks and better corporate sustainability performance. Among the key international policy developments that underpin the increasing number of stock exchange initiatives on sustainability, the main is the outcome of Rio+20 United Nations Conference on Sustainable Development. European Commission has also adopted a proposal for a directive enhancing the transparency of companies on social and environmental matters on April 16, 2013 by changing existing Accounting Directives. Earlier on 6 February 2013, the European Parliament had adopted two resolutions connected with Social Responsibility ("Corporate Social Responsibility: accountable, transparent and responsible business behaviour and sustainable growth" and "Corporate Social Responsibility: promoting society's interests and a route to sustainable and inclusive recovery"), acknowledging the importance of company transparency on environmental and social matters (Promoting Sustainable Development: The Way Forward for a Sustainability Index in Turkey 2014).

Despite being in the position to promote sustainability, stock exchanges are concerned about imposing more strict regulations or listing requirements that might discourage future listings. Sustainability Indices based on ratings using voluntary public disclosure appear to be one of the preferred instruments used 
by the exchanges to encourage transparency of corporate sustainability indicators without mandatory rules. Such indices highlight top performers, facilitating investor pressure and competition between companies to drive disclosure, and ultimately better performance, in the long term. Tough but flexible regulations are conduit to improving a country's competitiveness through innovation (Porter, Linde 1995). Lower the environmental and social local standards, higher would be the costs of adopting better sustainability practices for individual firms.

\section{THE RESEARCH METHODOLOGY AND THE COURSE OF THE RESEARCH PROCESS}

The aim of this article is to assess the level of stock exchanges sustainability support and test the correlation between the stock market size and sustainability support level. The research is based on the data from Sustainable Stock Exchange Initiative survey (Sustainable Stock Exchange. Report on progress 2012). The SSE initiative is a joint project organised by the United Nations-backed Principles for Responsible Investment (PRI), the United Nations Conference on Trade and Development (UNCTAD), the United Nations Environment Programme Finance Initiative (UNEP-FI), and the United Nations Global Compact (UNGC). This study was completed using a combination of publicly available information, survey responses and findings at the time of research. Exchange entity ownership information was accessed from Bloomberg, January 2012.

27 Stock Exchanges all over the world were surveyed in 2012 and described in this publication. An exchange entity could refer to either the holding company of a single or multiple exchanges or a single exchange.

There was 19 questions in the survey made in 2012. For this research purpose 4 questions was considered as the most important. Selection was made taking into account assessment objectivity and comprehensiveness. Important in the selection proces was also data reliability. Assumption was that variables are the various actions associated with: internal regulations, external regulations, investors and listed companies.

The questions used to conduct a research in this article were as follows:

- Does the exchange make its own ESG disclosures?

- Is the exchange a signatory of PRI?

- Has the exchange launched sustainability related indices?

- Has the exchange offered sustainability guidance for listing companies? 
Answers to the questions in the conducted questionnaire allowed to asses overall sustainability support level on a scale from 0 to 1 in four categories (ESG disclosure, PRI signatories, sustainability indices, sustainability guidance for listing companies). Each category has been proposed as support variable assessing stock exchanges sustainability. All variables were assigned equal weights.

On basis of described 4 variables the Sustainability Support Index (SSI) was created in this article. SSI is the sum of selected variables. The Sustainability Support Index formula is presented below.

$$
S S I=\sum_{i=1}^{4} x_{i}
$$

SSI - Sustainability Support Index

$x_{1}$ - ESG disclosure (Yes - 1, No - 0, GRI - 0,5)

$x_{2}$ - PRI signatories (Yes -1 , No - 0 )

$x_{3}$ - Sustainability Indices (Yes -1 , No - 0, Plan - 0,5)

$x_{4}$ - Sustainability guidance for listing companies (Yes -1 , No - 0 )

SSI is a stock markets sustainability support synthetic measure. It can be used to compare overall stock exchange sustainability support level. The SSI index may not reflect all sustainability initiatives that exchanges have been internally pursuing or contemplating. This tool gives the opportunity of initial overall sustainability support assessment.

To analyze regional diversity additionally, the exchanges have been assigned to regions of the world (according to the World Bank methodology). Then the average value of SSI for each region was estimated to present geographical differences in the SSI value.

The next stage of the research was to analyse the correlation between characteristics that describe the exchange size (the number of listed companies and market capitalization) and the SSI level. It is based on Pearson's ratio.

\section{THE OUTCOME OF THE RESEARCH PROCESS AND CONCLUSIONS}

Sustainability Support Index was calculated on 27 stock exchanges. Results and source data are presented in table 1 . as a SSI ranking. 
Table 1. Sustainable Support Index ranking

\begin{tabular}{|c|c|c|c|c|c|c|c|c|c|c|}
\hline 突 & $\begin{array}{c}\text { Stock } \\
\text { Exchanges }\end{array}$ & Country & $\begin{array}{c}\text { Number } \\
\text { of listed } \\
\text { companies } \\
(2012)\end{array}$ & $\begin{array}{c}\text { Market } \\
\text { capitaliza- } \\
\text { tion } 2012 \\
\text { (bln USD) }\end{array}$ & $\begin{array}{c}\text { Type } \\
\text { company }\end{array}$ & 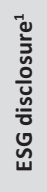 & 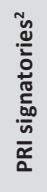 & 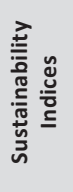 & 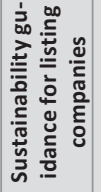 & 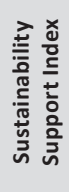 \\
\hline SSF & $\begin{array}{l}\text { Johannes- } \\
\text { burg Stock } \\
\text { Exchange }\end{array}$ & $\begin{array}{l}\text { South- } \\
\text {-Africa }\end{array}$ & 392.00 & 852.28 & $\begin{array}{l}\text { Listed } \\
\text { company } \\
\text { for profit }\end{array}$ & 1 & 1 & 1 & 1 & 4 \\
\hline LCN & $\begin{array}{l}\text { BM\&FBO- } \\
\text { VESPA }\end{array}$ & Brazil & 372.00 & 193.77 & $\begin{array}{l}\text { Listed } \\
\text { company } \\
\text { for profit }\end{array}$ & 0.5 & 1 & 1 & 1 & 3.5 \\
\hline EAS & $\begin{array}{l}\text { Korea } \\
\text { Exchange }\end{array}$ & Korea & 1816.00 & 1091.50 & $\begin{array}{l}\text { Demutuali- } \\
\text { zed company } \\
\text { for profit }\end{array}$ & 1 & 0 & 1 & 1 & 3 \\
\hline EAS & $\begin{array}{l}\text { Shanghai } \\
\text { Stock } \\
\text { Exchange }\end{array}$ & China & 932.00 & 2457.33 & $\begin{array}{l}\text { Association } \\
\text { not for profit }\end{array}$ & 1 & 0 & 1 & 1 & 3 \\
\hline EAS & $\begin{array}{l}\text { Bursa } \\
\text { Malaysia }\end{array}$ & Malaysia & 937.00 & 431.09 & $\begin{array}{l}\text { Listed } \\
\text { company } \\
\text { for profit }\end{array}$ & 1 & 0 & 0.5 & 1 & 2.5 \\
\hline ECS & $\begin{array}{l}\text { Deutsche } \\
\text { Börse AG }\end{array}$ & Germany & 742.00 & 1303.59 & $\begin{array}{l}\text { Listed } \\
\text { company } \\
\text { for profit }\end{array}$ & 0.5 & 0 & 1 & 1 & 2.5 \\
\hline ECS & $\begin{array}{l}\text { Istanbul } \\
\text { Stock } \\
\text { Exchange }\end{array}$ & Turkey & 264.00 & 232.69 & $\begin{array}{l}\text { Govern- } \\
\text { mental not } \\
\text { for profit }\end{array}$ & 1 & 1 & 0.5 & 0 & 2.5 \\
\hline ECS & $\begin{array}{l}\text { NYSE } \\
\text { Euronext }\end{array}$ & France & 3418.00 & 15187.61 & $\begin{array}{l}\text { Listed } \\
\text { company for } \\
\text { profit }\end{array}$ & 0.5 & 0 & 1 & 1 & 2.5 \\
\hline EAS & $\begin{array}{l}\text { Singapore } \\
\text { Exchange }\end{array}$ & Singapore & 772.00 & 665.73 & $\begin{array}{l}\text { Listed } \\
\text { company } \\
\text { for profit }\end{array}$ & 1 & 0 & 0.5 & 1 & 2.5 \\
\hline EAS & $\begin{array}{l}\text { The Stock } \\
\text { Exchange } \\
\text { of Thailand }\end{array}$ & Thailand & 545.00 & 289.75 & $\begin{array}{l}\text { Govern- } \\
\text { mental not } \\
\text { for profit }\end{array}$ & 1 & 0 & 0.5 & 1 & 2.5 \\
\hline ECS & $\begin{array}{l}\text { BME } \\
\text { Spanish } \\
\text { Exchanges }\end{array}$ & Spain & 3263.00 & 1096.20 & $\begin{array}{l}\text { Listed } \\
\text { company } \\
\text { for profit }\end{array}$ & 1 & 0 & 1 & - & 2 \\
\hline ECS & $\begin{array}{l}\text { London } \\
\text { Stock } \\
\text { Exchange }\end{array}$ & UK & 2864.00 & 3397.13 & $\begin{array}{l}\text { Listed } \\
\text { company } \\
\text { for profit }\end{array}$ & 1 & 0 & 1 & 0 & 2 \\
\hline NAC & $\begin{array}{l}\text { Nasdaq } \\
\text { OMX }\end{array}$ & US & 3440.00 & 5057.58 & $\begin{array}{l}\text { Public } \\
\text { company } \\
\text { for profit }\end{array}$ & 0 & 0 & 1 & 1 & 2 \\
\hline
\end{tabular}




\begin{tabular}{|c|c|c|c|c|c|c|c|c|c|c|}
\hline $\begin{array}{l}\stackrel{5}{\circ} \\
\stackrel{0}{0} \\
\stackrel{0}{\infty}\end{array}$ & $\begin{array}{c}\text { Stock } \\
\text { Exchanges }\end{array}$ & Country & $\begin{array}{c}\text { Number } \\
\text { of listed } \\
\text { companies } \\
\text { (2012) }\end{array}$ & $\begin{array}{c}\text { Market } \\
\text { capitaliza- } \\
\text { tion } 2012 \\
\text { (bln USD) }\end{array}$ & $\begin{array}{c}\text { Type } \\
\text { company }\end{array}$ & 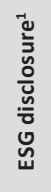 & 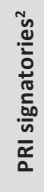 & 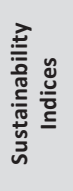 & 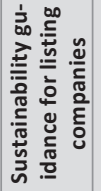 & 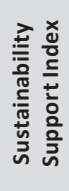 \\
\hline NAC & $\begin{array}{l}\text { Toronto } \\
\text { Stock } \\
\text { Exchange }\end{array}$ & Canada & 3947.00 & 2014.47 & $\begin{array}{l}\text { Listed } \\
\text { company } \\
\text { for profit }\end{array}$ & 0 & 0 & 1 & 1 & 2 \\
\hline EAS & $\begin{array}{l}\text { Hong Kong } \\
\text { Exchanges } \\
\text { and Cle- } \\
\text { aring }\end{array}$ & $\begin{array}{l}\text { Hong- } \\
\text {-Kong }\end{array}$ & 1506.00 & 2480.18 & $\begin{array}{l}\text { Listed } \\
\text { company } \\
\text { for profit }\end{array}$ & 0.5 & 0 & 0 & 1 & 1.5 \\
\hline ECS & $\begin{array}{l}\text { SIX Swiss } \\
\text { Exchange }\end{array}$ & $\begin{array}{l}\text { Switzer- } \\
\text { land }\end{array}$ & 280.00 & 1122.74 & $\begin{array}{l}\text { Private } \\
\text { company not } \\
\text { for profit }\end{array}$ & 1 & 0 & 0.5 & 0 & 1.5 \\
\hline LCN & $\begin{array}{l}\text { Bolsa } \\
\text { Mexicana } \\
\text { de Valores }\end{array}$ & Mexico & 476.00 & 441.41 & $\begin{array}{l}\text { Listed } \\
\text { company } \\
\text { for profit }\end{array}$ & 0 & 0 & 1 & - & 1 \\
\hline SAS & $\begin{array}{l}\text { Bombay } \\
\text { Stock } \\
\text { Exchanges }\end{array}$ & India & 5115.00 & 1225.47 & $\begin{array}{l}\text { Demutuali- } \\
\text { zed }\end{array}$ & 0 & 0 & 1 & - & 1 \\
\hline EAS & $\begin{array}{l}\text { Indonesia } \\
\text { Stock } \\
\text { Exchange }\end{array}$ & Indonesia & 442.00 & 407.71 & $\begin{array}{l}\text { Private } \\
\text { company } \\
\text { for profit }\end{array}$ & 0 & 0 & 1 & - & 1 \\
\hline SAS & $\begin{array}{l}\text { National } \\
\text { Stock } \\
\text { Exchange } \\
\text { of India }\end{array}$ & India & 1641.00 & 1200.74 & $\begin{array}{l}\text { Demutuali- } \\
\text { zed company } \\
\text { for profit }\end{array}$ & 0 & 0 & 1 & 0 & 1 \\
\hline EAS & $\begin{array}{l}\text { Shenzhen } \\
\text { Stock } \\
\text { Exchange }\end{array}$ & China & 1420.00 & 1044.60 & $\begin{array}{l}\text { Association } \\
\text { not for profit }\end{array}$ & 1 & 0 & - & - & 1 \\
\hline EAS & $\begin{array}{l}\text { Tokyo Stock } \\
\text { Exchange }\end{array}$ & Japan & 2288.00 & 3468.88 & $\begin{array}{l}\text { Demutuali- } \\
\text { zed company } \\
\text { for profit }\end{array}$ & 0 & 0 & 1 & 0 & 1 \\
\hline EAS & $\begin{array}{l}\text { Philippi- } \\
\text { ne Stock } \\
\text { Exchange }\end{array}$ & $\begin{array}{l}\text { Philippi- } \\
\text { nes }\end{array}$ & 253.00 & 175.89 & $\begin{array}{l}\text { Association } \\
\text { not for profit }\end{array}$ & 0 & 0 & 0.5 & 0 & 0.5 \\
\hline EAS & $\begin{array}{l}\text { Australian } \\
\text { Stock } \\
\text { Exchange }\end{array}$ & Australia & 2078.00 & 1303.81 & $\begin{array}{l}\text { Listed } \\
\text { company } \\
\text { for profit }\end{array}$ & 0 & 0 & 0 & 0 & 0 \\
\hline LCN & $\begin{array}{l}\text { Bolsa de } \\
\text { Comercio } \\
\text { de Santiago } \\
\text { - Santia- } \\
\text { go Stock } \\
\text { Exchange }\end{array}$ & Chile & 266.00 & 290.37 & $\begin{array}{l}\text { Listed } \\
\text { company } \\
\text { for profit }\end{array}$ & 0 & 0 & 0 & 0 & 0 \\
\hline
\end{tabular}




\begin{tabular}{|c|c|c|c|c|c|c|c|c|c|c|}
\hline 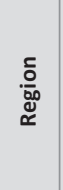 & $\begin{array}{c}\text { Stock } \\
\text { Exchanges }\end{array}$ & Country & $\begin{array}{c}\text { Number } \\
\text { of listed } \\
\text { companies } \\
(2012)\end{array}$ & $\begin{array}{c}\text { Market } \\
\text { capitaliza- } \\
\text { tion } 2012 \\
\text { (bln USD) }\end{array}$ & $\begin{array}{c}\text { Type } \\
\text { company }\end{array}$ & 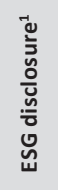 & 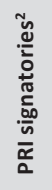 & 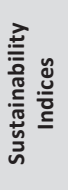 & 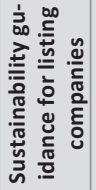 & 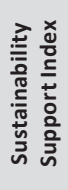 \\
\hline ECS & $\begin{array}{l}\text { Moscow } \\
\text { Interbank } \\
\text { Currency } \\
\text { Exchange }\end{array}$ & Russia & 284.00 & 770.61 & $\begin{array}{l}\text { Private } \\
\text { company } \\
\text { for profit }\end{array}$ & 0 & 0 & 0 & . & 0 \\
\hline MEA & $\begin{array}{l}\text { Saudi Stock } \\
\text { Market - } \\
\text { Tadawul }\end{array}$ & $\begin{array}{l}\text { Saudi } \\
\text { Arabia }\end{array}$ & 150.00 & 347.49 & $\begin{array}{l}\text { Govern- } \\
\text { mental not } \\
\text { for profit }\end{array}$ & 0 & 0 & 0 & - & 0 \\
\hline
\end{tabular}

1 ESG - Environmental, Social, and Corporate Governance

2 PRI - Principles for Responsible Investment

S o u r c e : own study based on: Sustainable Stock Exchange. Report on progress, Sustainable Stock Exchange Initiative 2012.

In the table 1 there are values between 0 and 1 in columns $7-10$. Numbers are interpreted as follows: 1 - yes, 0 - no, 0.5 in column 7 means "GRI ${ }^{1}$ disclosure", 0.5 in column 9 means "is planning".

The highest SSI index level is observed on Johannesburg Stock Exchange (4). Slightly lower level (3.5) is in Brazil (BM\&FBOVESPA). In Korea (Korea Exchange) and China (Shanghai Stock Exchange) SSI is on level 3. The lowest sustainability support indicator is observed in Saudi Arabia (Saudi Stock Market - Tadawul), Russia (Moscow Interbank Currency Exchange), Chile (Santiago Stock Exchange) and Australia (Australian Stock Exchange). This markets reached level 0 in this category.

At this stage of the research it is worth to examining regional differences in SSI index. To perform such an analysis countries have been assigned to world regions. The division is based on the World Bank methodology (World Bank).

Table 2. World regions

\begin{tabular}{|l|l|}
\hline \hline \multicolumn{1}{|c|}{ Region symbol } & \multicolumn{1}{c|}{ Region name } \\
\hline \hline EAS & East Asia \\
\hline ECS & Europe \& Central Asia \\
\hline LCN & Latin America \\
\hline
\end{tabular}

1 GRI - Global Reporting Initiative 


\begin{tabular}{|l|l|}
\hline \hline \multicolumn{1}{|c|}{ Region symbol } & \multicolumn{1}{c|}{ Region name } \\
\hline \hline SAS & South Asia \\
\hline SSF & Sub-Saharan Africa \\
\hline MEA & Middle East \& North Africa \\
\hline NAC & North America \\
\hline \hline
\end{tabular}

S o u r c e : World Bank.

The mean SSI value in the research sample amounts to 1.7 (figure 1). The highest sustainability support level is observed in Sub-Saharan Africa (4). The research covered only one stock exchange in this region: Johanesburg Stock Exchange. Second in terms of the SSI value is North American region (2). The third region is Europe \& Central Asia (1.86). Then East Asia (1.68) and Latin America (1.50). The lowest sustainability support level is observed in South Asia (1) and Middle East \& North Africa (0).

Figure 1. Sustainability Support Index in world regions

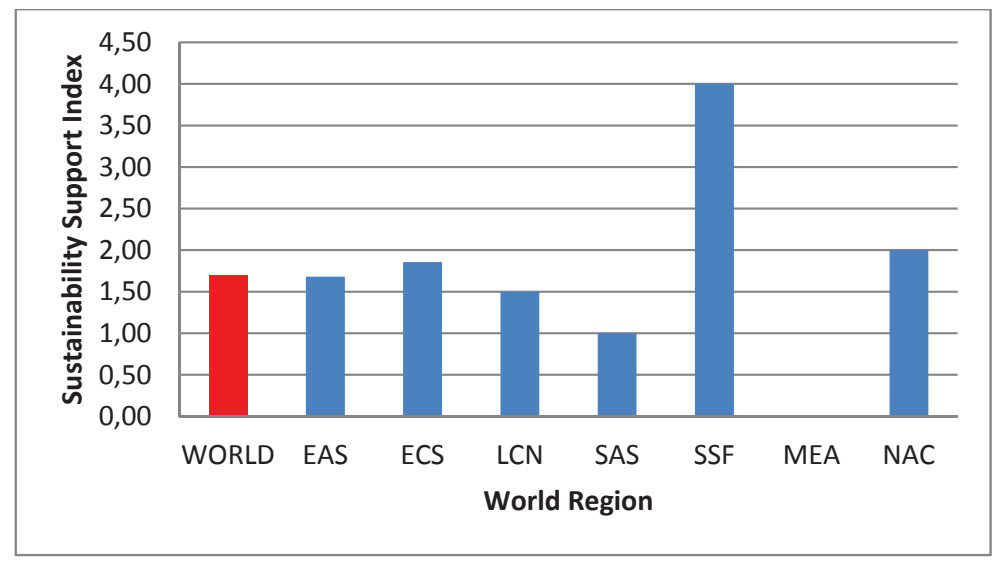

S o u r c e : own study.

Diversed levels of SSI raise a question about the factors affecting the level of sustainability support. Is there a relationship between the Sustainability Support Index level and the stock market size? To answer this question stock market size variables and the SSI level can be compared. The market size can be 
measured by different variables. Two of them have been used in this research: a number of listed companies and market capitalization. The SSI ratio will be related to "number of listed companies" and "market capitalization" in this section of the article.

There is a neutral relationship between SSI and number of listed companies variables. The linear regression line is very flat in this case. Studied variables of Pearson's correlation ratio amount to 0.0262 . This confirms the low relationship between the variables.

The second variable describing the stock market size is market capitalization. A higher correlation level between SSI ratio and market capitalization is conspicuous. Pearson's correlation ratio amounts to 0.1621 . The regression line is still flat, but a positive tendency is noticeable. In both cases SSI ratio volatility is reduced with market size increasing.

The next research step was to assess the correlation between stock exchange size variables and sustainable support sub-variables using Pearson's ratio. The highest positive correlation level occurs between "Sustainability Indices" and "Number of listed companies" (0.4277). Negative correlation appears between "PRI signatories" and "number of listed companies" (-0.2972).

Table 3. Pearson's correlation ratio of stock market size variables and stock market sustainability support variables

\begin{tabular}{|l|c|c|}
\hline \hline & Number of listed companies & Market capitalization \\
\hline \hline Sustainability Support Index & 0.0262 & 0.1621 \\
\hline ESG disclosure & -0.1611 & -0.0311 \\
\hline PRI signatories & -0.2972 & -0.1689 \\
\hline Sustainability Indices & 0.4277 & 0.2661 \\
\hline Sustainability guidance for listing companies & 0.1363 & 0.1912 \\
\hline \hline
\end{tabular}

S o u r c e : own study.

There is a weak correlation between sustainability support variables and stock market size variables. It should be stressed that there is no significant relationship between market size variables and sustainability support variables. Some relations are positive and some negative.

Concluding the research it is worth pointing out that:

1. The highest sustainability level occurs in Johanesburg Stock Exchange, BM\&FBOVESPA, Korea Exchange, Shanghai Stock Exchange. The lo- 
west sustainability level is in Australian Stock Exchange, Santiago Stock Exchange, Moscow Interbank Currency Exchange, Saudi Stock Market Tadawul.

2. The highest level of Sustainability Support Index is observed in Sub-Saharan Africa. It is interesting that it is based on one stock exchange. A high level also is observed in North America and Europe \& Central Asia. The lowest SSI ratio is in Middle East \& North Africa, South Asia and Latin America.

3. The sustainability support level is weakly correlated with the market size in view of considering "number of listed companies" and "market capitalization". Pearson's correlation ratio amounts to 0.0262 and 0.1621 .

4. A deeper analysis of sub-variables confirms a weak relationship between sustainability support and the stock market size. Pearson's correlation ratio ranges from -0.2972 to 0.4277 . This relationship should be considered as weak.

In author's opinion it is worth to develop stock market sustainability support research in the future. A measurement tool proposed in this article can be used in the sustainability support dynamic analysis. It can be modified depending on needs.

As shown in the article the biggest Stock Exchanges began to compete not only by number of listed companies or capitalization but also by sustainability aspects. Less developed markets, like Polish are not engaged in this process. In the future taking care of stock market sustainability is inevitable. Participation in this process could become a distinguishing feature for exchanges such as Warsaw Stock Exchange.

\section{REFERENCES}

Banerjee S.B. (2011). Embedding Sustainability across the Organization: A Critical Perspective. Academy of Management Learning \& Education, 10 (4), 719-731. http:// dx.doi.org/10.5465/amle.2010.0005.

Dyllick T., Muff K. (2013). Clarifying the Meaning of Sustainable Business, Introducing a Typology from Business-As-Usual to True Business Sustainability. http://dx.doi. org/10.2139/ssrn.2368735.

Hart S.L. (2007), Capitalism at the Crossroads. 2nd ed. Upper Saddle River, NJ: Wharton School Publishing.

Margolis, J. and Walsh, J. (2003). Misery Loves Companies: Rethinking Social Initiatives by Business. Administrative Science Quarterly, 48 (2), 268-305. http://dx.doi. org/10.2307/3556659. 
Nidumolu R., Prahalad, C.K., Rangaswami M.R. (2009). Why Sustainability Is Now the Key Driver of Innovation. Harvard Business Review, 87 (9), 57-64. http://dx.doi. org/10.1109/EMR.2013.6601104.

Porter M.E. and Claas van der Linde (1995). Toward a New Conception of the Environment Competitiveness Relationship. Journal of Economic Perspectives, 9 (4), 97-118. http://dx.doi.org/10.1257/jep.9.4.97.

Prahalad C.K. \& Hammond A. (2002). Serving the World's Poor, Profitably. Harvard Business Review, 80 (9), 48-55.

Prahalad C.K. (2004). The Fortune at the Bottom of the Pyramid: Eradicating Poverty through Profits. Upper Saddle River, NJ: Wharton School Publishing.

Promoting Sustainable Development: The Way Forward for a Sustainability Index in Turkey (2014). Sabanci University.

Sustainable Stock Exchange. Report on progress (2012), Sustainable Stock Exchanges Initiative, http://www.sseinitiative.org/publications/ (accessed: 15.03.2014).

World Bank, http://www.worldbank.com (accessed: 15.03.2014). 